\title{
Ultrastructural Aspects of Autolysis of Pseudomonas fluorescens Induced by Osmotic Shock
}

\author{
By ANA M. PARENTE* AND MANUEL T. SILVA \\ Instituto de Botânica e Centro de Citologia Experimental da Universidade do Porto, \\ Rua Campo Alegre 1021, 4100 Porto, Portugal
}

(Received 30 December 1983)

\begin{abstract}
Autolysis of exponentially growing Pseudomonas fluorescens was induced by a rapid treatment with distilled water before treatment with $0.5 \mathrm{M}$-sodium acetate, $\mathrm{pH} 6.5$, and incubation for $2 \mathrm{~h}$ at $30^{\circ} \mathrm{C}$. Electron microscopy revealed three stages of autolysis. In the first stage most of the cells were plasmolysed. In the second stage (from 5 to $20 \mathrm{~min}$ ) the number of plasmolysed cells diminished, the profile of the outer membrane changed from asymmetric to symmetric, fractures appeared in the outer membrane and signs of peptidoglycan degradation became apparent. In the third stage (which began after 20 to $60 \mathrm{~min}$ ) the ultrastructural alterations of the cell wall became more serious, the cytoplasmic membrane exhibited micromorphological lesions and progressive cellular disintegration occurred. The addition of chloramphenicol $\left(100 \mu \mathrm{g} \mathrm{ml}^{-1}\right)$ or tetracycline $\left(4 \cdot 5 \mu \mathrm{g} \mathrm{ml}^{-1}\right)$, to either the culture or the suspensions of autolysing cells, did not significantly reduce the rate of autolysis. The presence of $\mathrm{Ca}^{2+}$ or $\mathrm{Mg}^{2+}(10 \mathrm{mM})$ in the autolytic medium inhibited autolysis and there were no significant ultrastructural alterations. The presence of $2 \mathrm{mM}-\mathrm{N}$-bromosuccinimide (an inhibitor of bacterial autolytic enzymes) in the autolytic medium strongly inhibited autolysis of $P$. fluorescens; however, the bacteria incubated under these conditions showed significant ultrastructural alterations (extensive splitting of, and occasional fractures in, the outer membrane; cytoplasmic membrane and ribosomes not visible).
\end{abstract}

\section{INTRODUCTION}

The lytic process of bacteria depends on a mechanically resistant cell wall that gives osmotic protection (Epstein \& Schultz, 1968; Ghuysen, 1977; Stolp \& Starr, 1965). For lysis to occur, specific enzymes that hydrolyse peptidoglycan linkages are necessary to disintegrate the cell wall (Shockman, 1965; Stolp \& Starr, 1965). During autolysis the degradation of peptidoglycan by endogenous peptidoglycan hydrolases (autolytic enzymes) occurs when they are activated. Because the envelope structure of Gram-negative bacteria is more differentiated than that of Gram-positive bacteria (there is an extra membrane system outside a thin peptidoglycan layer) the autolytic process is more complex. Different factors, such as growth conditions, osmotic environment and $\mathrm{pH}$, have been recognized as being particularly important in autolysis (Shockman, 1965). However, the conditions leading to autolysis remain largely unknown. A set of peptidoglycan hydrolases has been demonstrated in Escherichia coli (Daneo-Moore \& Shockman, 1977; Ghuysen, 1977; Mirelman, 1979). Their actual in vivo function and participation in autolysis are not yet well defined. Autolysis of $E$. coli was promoted by submitting the cells to a rapid treatment with distilled water, followed by treatment with $0.5 \mathrm{M}$ sodium acetate, pH 6.5 (Leduc \& van Heijenoort, 1980). With this double-shock treatment a $60 \%$ decrease in the absorbance at $600 \mathrm{~nm}$ was observed. These authors also established a correlation between autolysis and the degradation of peptidoglycan as well as the effect of divalent cations on autolysis. 
The results presented here refer to the spectrophotometric and ultrastructural study of the autolysis of $P$. fluorescens induced by the double-shock method of Leduc \& van Heijenoort (1980). The effects on autolysis of inhibitors of protein synthesis (chloramphenicol and tetracycline), of an autolysin inhibitor ( $N$-bromosuccinimide), and of divalent cations $\left(\mathrm{Ca}^{2+}\right.$ and $\mathrm{Mg}^{2+}$ ) are also described.

Since Gram-negative bacteria are known to be resistant to non-ionic detergents due to the impermeability of their outer membrane (Birdsell \& Cota-Robles, 1968), we used Triton X-100 as an indicator of the integrity of the outer membrane of $P$. fluorescens during the autolytic process.

\section{METHODS}

Organism and culture conditions. Pseudomonas fluorescens strain X4A was grown in $1.0 \%(\mathrm{w} / \mathrm{v})$ tryptone (Difco), $0.5 \%(\mathrm{w} / \mathrm{v})$ yeast extract (Difco), $0.4 \%(\mathrm{w} / \mathrm{v}) \mathrm{KCl}, \mathrm{pH} 7 \cdot 2$, at $30^{\circ} \mathrm{C}$ with shaking to about $A_{578}=0.2$. An overnight culture was used as inoculum. Cells from a $30 \mathrm{ml}$ culture were harvested by centrifugation at room temperature for $5 \mathrm{~min}$ at $6000 \mathrm{~g}$. These pellets were used either for the autolytic process or to make suspensions in $0.5 \mathrm{M}$-sodium acetate buffer, pH 6.5, 0.05 M-phosphate buffer, pH 7.0, $0.3 \mathrm{M}$-sucrose, $10 \%(\mathrm{w} / \mathrm{v})$ polyethylene glycol or distilled water.

Autolysis procedure. To induce autolysis the bacteria were quickly suspended by vigorous agitation (vortex mixing) in $8 \mathrm{ml}$ distilled water at $30^{\circ} \mathrm{C} ; 20 \mathrm{~s}$ later $8 \mathrm{ml} 1 \mathrm{M}$-sodium acetate, $\mathrm{pH} 6.5$, at $30^{\circ} \mathrm{C}$ was added and then the bacteria were incubated for $2 \mathrm{~h}$ at $30^{\circ} \mathrm{C}$, without shaking (Leduc \& van Heijenoort, 1980). Lysis was followed by measuring the decrease in $A_{578}$.

Treatment of bacteria. Divalent cations $\left(\mathrm{Ca}^{2+}\right.$ or $\left.\mathrm{Mg}^{2+}\right)$ at final concentrations of 10 or $100 \mathrm{mM}$ were added to the sodium acetate, to the cell suspensions undergoing autolysis ( $30 \mathrm{~min}$ after the beginning of the autolytic process) or to cell suspensions made directly in $0.5 \mathrm{M}$-sodium acetate, $\mathrm{pH} \mathrm{6.5}$. Chloramphenicol (Sigma) or tetracycline (Sigma) at final concentrations of $100 \mu \mathrm{g} \mathrm{ml}^{-1}$ and $4.5 \mu \mathrm{g} \mathrm{ml}^{-1}$, respectively, were added to the cultures $\left(A_{578}=0.2\right) 20$ min before harvesting of bacteria, or to cell suspensions undergoing autolysis immediately after the osmotic shock. Treatment with Triton X-100 (BDH) at a final concentration of $2 \mathrm{mM}$ was done by adding the detergent at different times to suspensions of autolysing cells (with or without $\mathrm{Ca}^{2+}$ or $\mathrm{Mg}^{2+}$ ) and to cell suspensions made directly in $0.5 \mathrm{M}$-sodium acetate, $\mathrm{pH} 6.5$ (with or without $\mathrm{Ca}^{2+}$ or $\mathrm{Mg}^{2+}$ ) or in distilled water.

$\mathrm{N}$-Bromosuccinimide (Sigma) at final concentrations of 1 or $2 \mathrm{mM}$ was added to the autolysing suspensions after

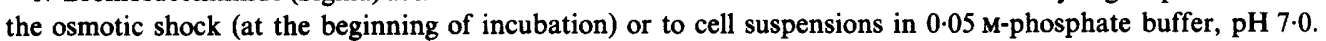

Sucrose (final concentration $0.3 \mathrm{M}$ ) or polyethylene glycol (final concentration $10 \%, \mathrm{w} / \mathrm{v}$ ) was used in place of sodium acetate in the described double-shock procedure.

Electron microscopy. Bacteria were fixed by adding stock $25 \%(\mathrm{w} / \mathrm{v})$ glutaraldehyde (TAAB Laboratories, Reading, UK) to a final concentration of $1.25 \%(\mathrm{w} / \mathrm{v})$. After $60 \mathrm{~min}$ at room temperature, the cells were pelleted by centrifugation and postfixed with $\mathrm{OsO}_{4}$ (Ryter \& Kellenberger, 1958), followed by $1.0 \%$ (w/v) aqueous uranyl acetate, and then processed for ultramicrotomy by embedding in Epon (Luft, 1961). The ultrathin sections were contrasted with uranyl acetate (aqueous saturated solution) for $10 \mathrm{~min}$ followed by lead citrate (Venable \& Coggeshall, 1965) for $5 \mathrm{~min}$, and were then observed under a Siemens Elmiskop IA transmission electron microscope.

Tracings of the outer membrane profiles were made on photographic negatives with a Joyce-Loebl MK III CS microdensitometer, working with an arm ratio of $50 \times$ and a slit of $0.5 \mathrm{~nm}$.

\section{RESULTS}

\section{Spectrophotometric and ultrastructural study of autolysis}

Figure 1 depicts the typical ultrastructure of exponentially growing $P$. fluorescens cells $\left(A_{578}=0 \cdot 2\right)$. After treatment with distilled water the cells showed a lesser cytoplasmic density than the control cells and blebs of the outer membrane were observed (Fig. 2). The cells were plasmolysed $1 \mathrm{~min}$ after the exposure of the cell suspensions directly to $0.5 \mathrm{M}$-sodium acetate. Deplasmolysis had occurred in almost all of the bacteria 30 min later, which explains the observed $38 \%$ decrease in $A_{578}$. In some cells, fractures of the outer membrane became visible. When cell suspensions were made directly in $0.3 \mathrm{M}$-sucrose or $10 \%(\mathrm{w} / \mathrm{v})$ polyethylene glycol, the decrease in $A_{578}$ during the first 30 min was $16 \%$ and $0 \%$, respectively. Two hours after the beginning of autolysis induced by double-osmotic shock an $80 \%$ decrease in $A_{578}$ was observed (Fig. 3). Ultrastructural examination revealed that the autolytic process was not synchronous and it was possible to consider three stages of autolysis. In samples harvested after $1 \mathrm{~min}$ incubation most of the bacteria had plasmolysed with large lacunae resulting from the proto- 


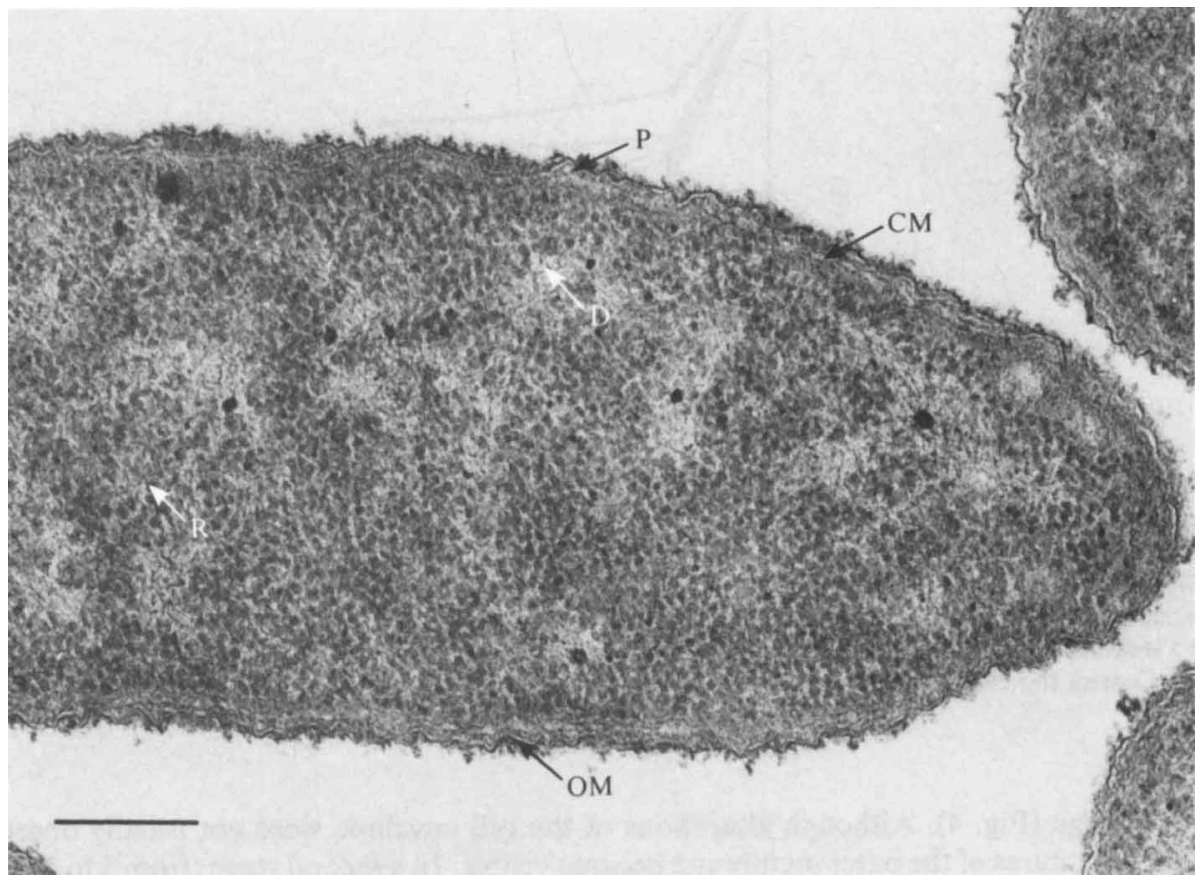

Fig. 1. Cells of $P$. fluorescens in exponential growth. CM, cytoplasmic membrane; OM, outer membrane; P, peptidoglycan; R, ribosome; D, DNA fibrils. Bar, $0 \cdot 2 \mu \mathrm{m}$.

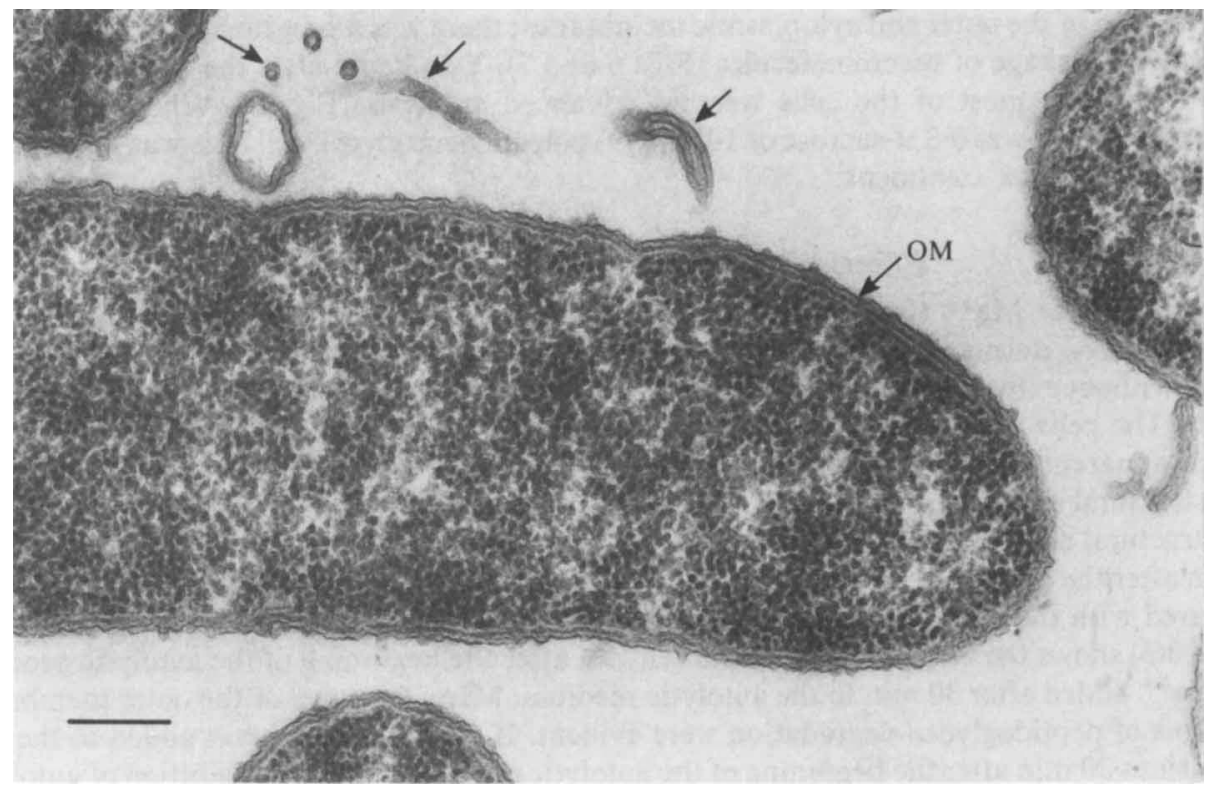

Fig. 2. Cells of $P$. fluorescens after treatment with distilled water. Notice the blebs (unlabelled arrows), of the outer membrane (OM). Bar, $0 \cdot 2 \mu \mathrm{m}$. 


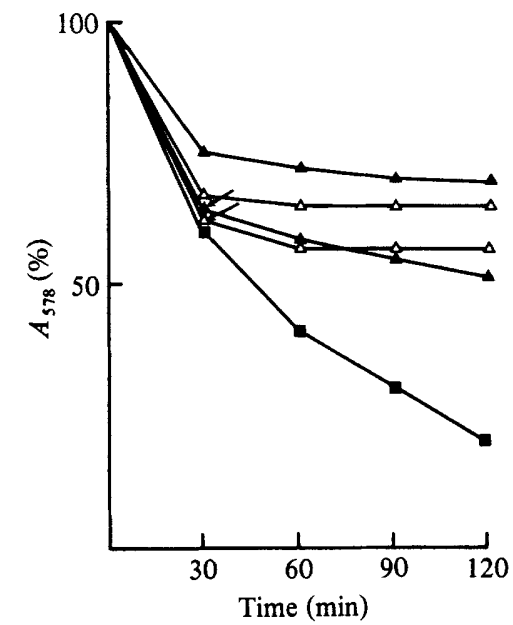

Fig. 3. Kinetics of autolysis and effect of cations $\left(\mathrm{Ca}^{2+}\right.$ and $\left.\mathrm{Mg}^{2+}\right)$ on autolysis of $P$. fluorescens induced by double-osmotic shock and incubation at $30^{\circ} \mathrm{C}$ for $2 \mathrm{~h} . \mathrm{Mg}^{2+}$ or $\mathrm{Ca}^{2+}(10 \mathrm{mM})$ was added to $0.5 \mathrm{M}$-sodium acetate or to autolysing cells $30 \mathrm{~min}$ after induction of autolysis as indicated by the arrows. $\square$, Control (no cations); $\Delta, \mathbf{M g}^{2+}$-treated cells; $\mathbf{\Delta}, \mathbf{C a}^{2+}$-treated cells.

plast shrinkage (Fig. 4). Although alterations of the cell envelope were not usually observed, occasional fractures of the outer membrane became visible. In a second stage (from 5 to $20 \mathrm{~min}$ ), deplasmolysis began, fractures of the outer membrane became evident, the profile of the membrane changed from asymmetric to symmetric and signs of peptidoglycan degradation became apparent (Fig. 5). Disorganized ribosomes appeared in some deplasmolysed cells. The decrease in $A_{578}$ observed during this stage was probably related to deplasmolysis. In a third stage, which began after 20 to $60 \mathrm{~min}$, the cells showed serious ultrastructural damage: the cell envelope showed extensive degradation of the peptidoglycan and fractures and partial solubilization of the outer and cytoplasmic membranes; there was a progressive cellular disintegration with leakage of macromolecules (Figs 6 and 7). Two hours after the beginning of the autolytic process most of the cells were in advanced autolysis (Fig. 8). When the second treatment utilized was $0.3 \mathrm{M}$-sucrose or $10 \%(\mathrm{w} / \mathrm{v})$ polyethylene glycol, cell lysis was not induced by the double-shock treatment.

\section{Effects of divalent cations $\left(\mathrm{Ca}^{2+}\right.$ and $\left.\mathrm{Mg}^{2+}\right)$}

When $\mathrm{Ca}^{2+}$ or $\mathrm{Mg}^{2+}$ (final concentration $10 \mathrm{mM}$ ) were added to $0.5 \mathrm{M}$-sodium acetate the decrease in $A_{578}$ during the initial 30 min was 15.0 and $7.5 \%$, respectively, lower than that of the control without extra cations (Fig. 3). These values at $30 \mathrm{~min}$ then remained almost unchanged for $2 \mathrm{~h}$. The cells were plasmolysed $1 \mathrm{~min}$ after the treatment with $\mathrm{Ca}^{2+}$ and deplasmolysis became apparent after $30 \mathrm{~min}$. This explained the decrease in $A_{578}$ observed during that phase. Ultrastructural examination of the $\mathrm{Ca}^{2+}$-treated cells $2 \mathrm{~h}$ after treatment showed no significant ultrastructural alterations (Fig. $9 a$ ). Addition of $\mathrm{Ca}^{2+}$ or $\mathrm{Mg}^{2+}(10 \mathrm{mM})$ to the cell suspensions 30 min after the beginning of the autolytic process resulted in the inhibition of autolysis. When compared with the control, the rate of autolysis was 31 and $37 \%$ lower, respectively (Fig. 3). Figure $9(b)$ shows the ultrastructure of the cells $1 \mathrm{~h}$ after the beginning of the autolytic process, with $\mathrm{Ca}^{2+}$ added after 30 min to the autolytic medium. Many fractures of the outer membrane and signs of peptidoglycan degradation were evident. If $\mathrm{Ca}^{2+}(100 \mathrm{mM})$ was added to the cell suspensions $30 \mathrm{~min}$ after the beginning of the autolytic process, a marked inhibition of autolysis occurred. Electron microscopy showed some cells with peptidoglycan degradation and fractures of the outer membrane; nevertheless, cell lysis did not occur. Cell suspensions made directly in $0.5 \mathrm{M}$-sodium acetate containing $\mathrm{Ca}^{2+}(10 \mathrm{mM})$ showed a decrease in $A_{578}$ during the first $30 \mathrm{~min}$ 


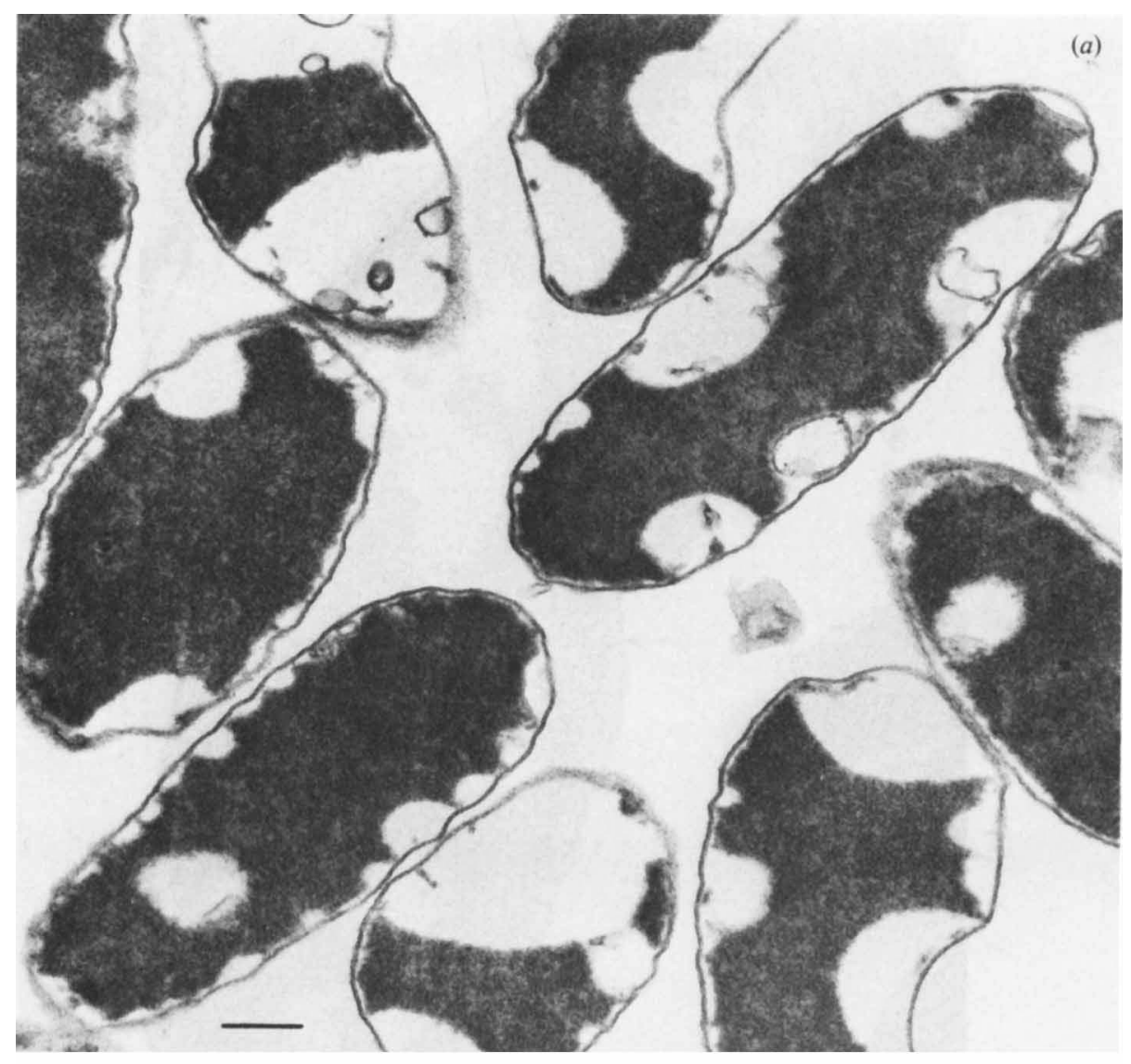

(b)

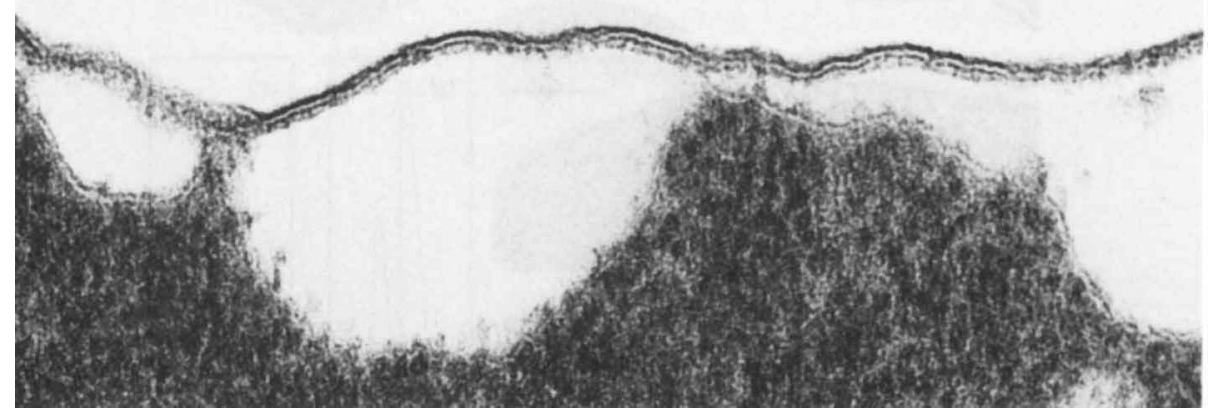

Fig. 4. Plasmolysed cells of $P$. fluorescens: (a) 1 min after the double-shock, showing large lacunae resulting from the protoplast shrinkage, bar $0.3 \mu \mathrm{m}$; (b) detail of the cell envelopes showing the asymmetric outer membrane, bar $0.1 \mu \mathrm{m}$.

of incubation similar to that of the control (no extra cations). However, when the final concentration of $\mathrm{Ca}^{2+}$ was $100 \mathrm{mM}$, the decrease in $A_{578}$ during the first 30 min was $20 \%$ lower than that of the control, and the ultrastructural examination revealed neither micromorphological alterations of the cell envelope nor plasmolysed cells. 



Fig. 5. Ultrastructure of $P$. fluorescens cells in suspensions subjected to double-osmotic shock. (a) Deplasmolysed cell at $5 \mathrm{~min}$; the outer membrane is asymmetric, as confirmed by the microdensitometric tracing $(d)$ of the zone marked by the unlabelled arrow. Bar, $0 \cdot 2 \mu \mathrm{m}$. (b) Cell fixed at $20 \mathrm{~min}$ showing the symmetric profile of the outer membrane, as confirmed by the microdensitometric tracing (e), and signs of peptidoglycan degradation, marked by the unlabelled arrows. Bar, $0 \cdot 1 \mu \mathrm{m}$. (c) As in $(b)$, showing fractures in the outer membrane (unlabelled arrows). Bar, $0 \cdot 1 \mu \mathrm{m}$. CM, cytoplasmic membrane; OM, outer membrane; P, peptidoglycan; R, ribosome; D, DNA fibrils. 


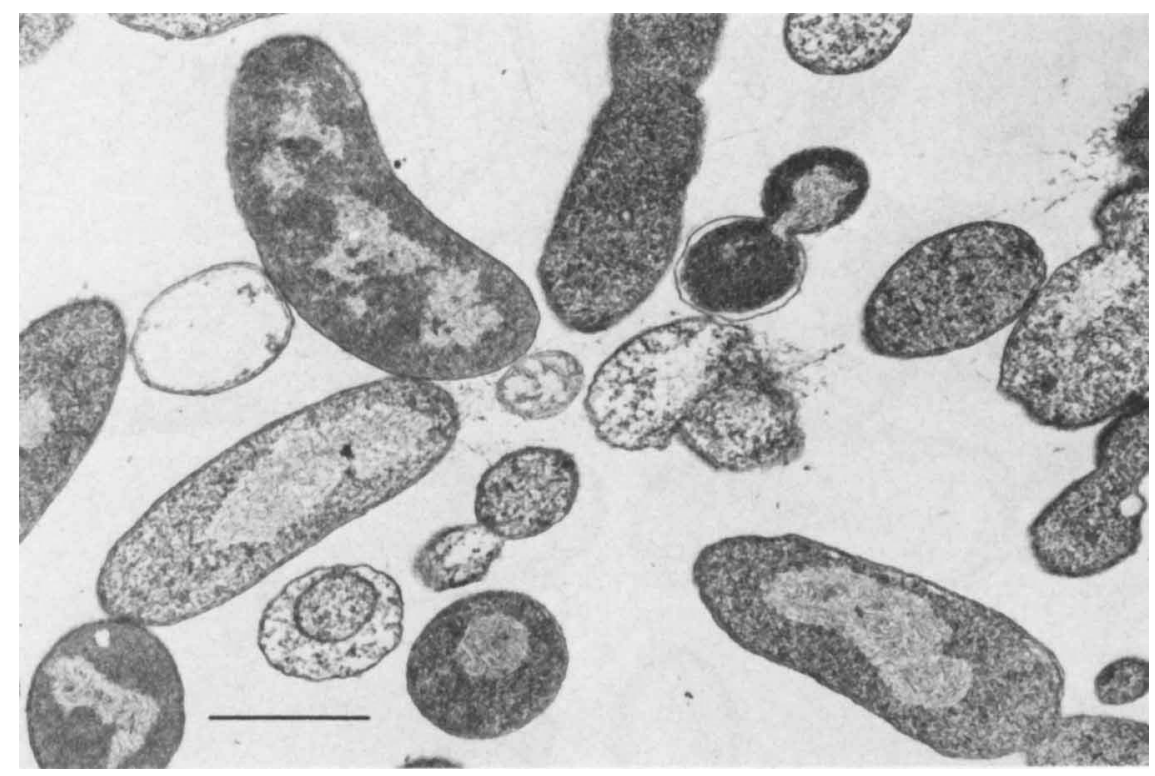

Fig. 6. Cells of $P$. fluorescens $1 \mathrm{~h}$ after the beginning of the autolytic process, showing different stages of progressive lysis. Bar, $1 \mu \mathrm{m}$.
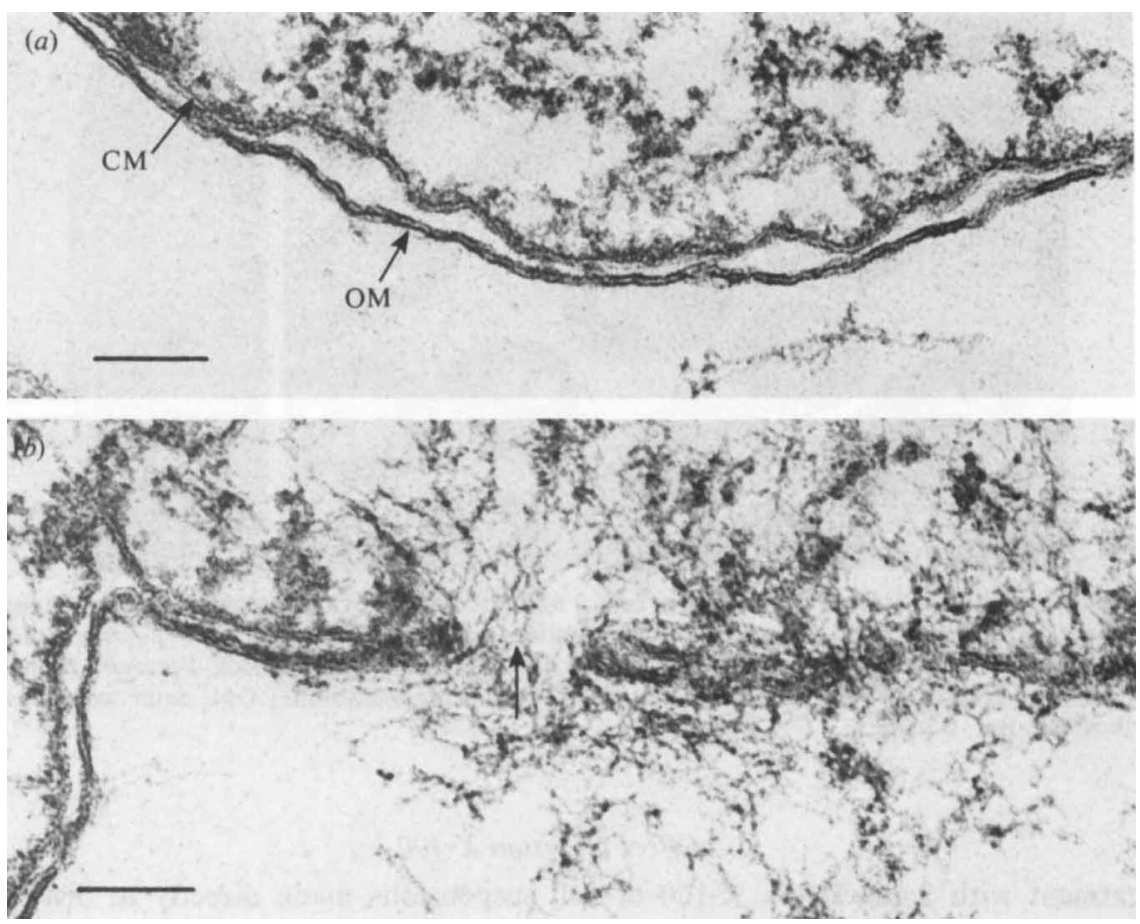

Fig. 7. Cells of $P$. fluorescens $1 \mathrm{~h}$ after the beginning of the autolytic process, in an advanced stage of lysis. Notice a rupture of the cell envelope (unlabelled arrow) in $(b)$; the peptidoglycan layer is absent in $(a)$ and $(b)$. OM, outer membrane; CM, cytoplasmic membrane. Bars, $0 \cdot 1 \mu \mathrm{m}$. 


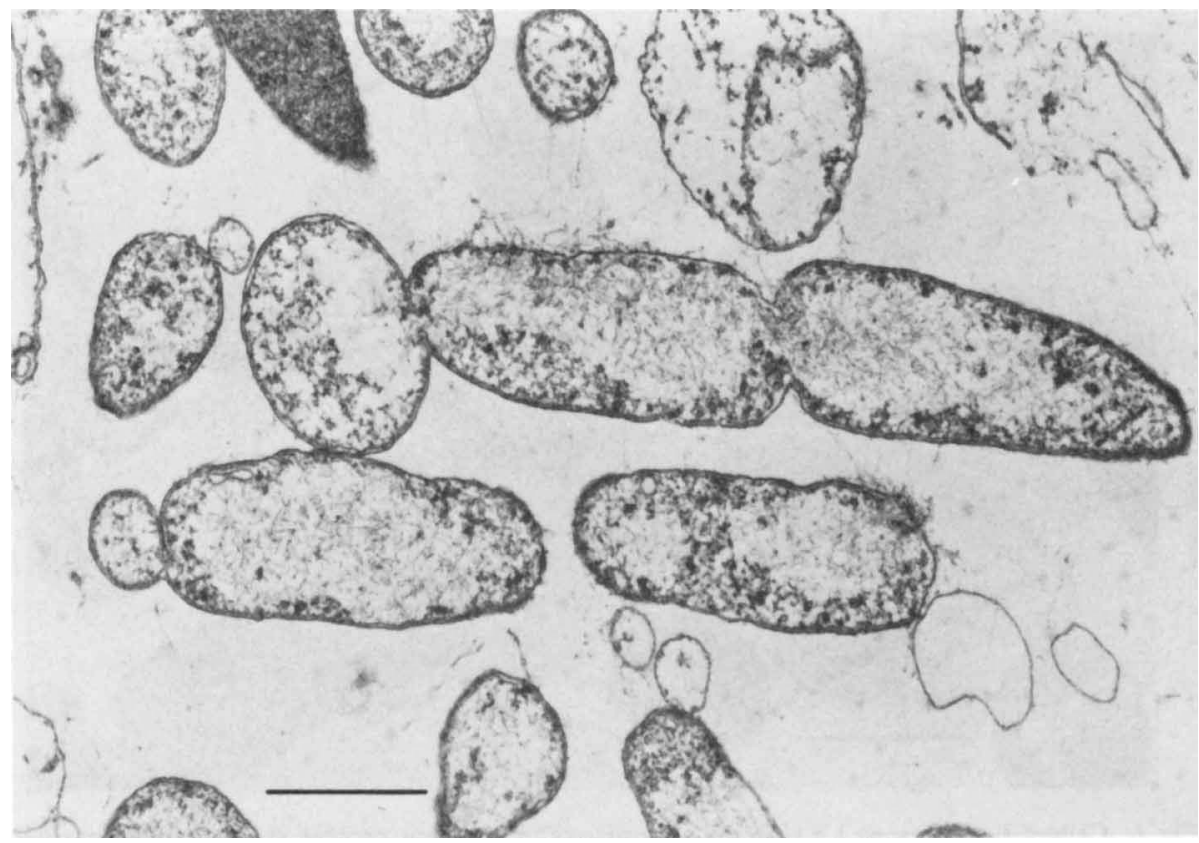

Fig. 8. Ultrastructure of $P$. fluorescens cells under advanced lysis $2 \mathrm{~h}$ after double-shock treatment. Bar, $1 \mu \mathrm{m}$.
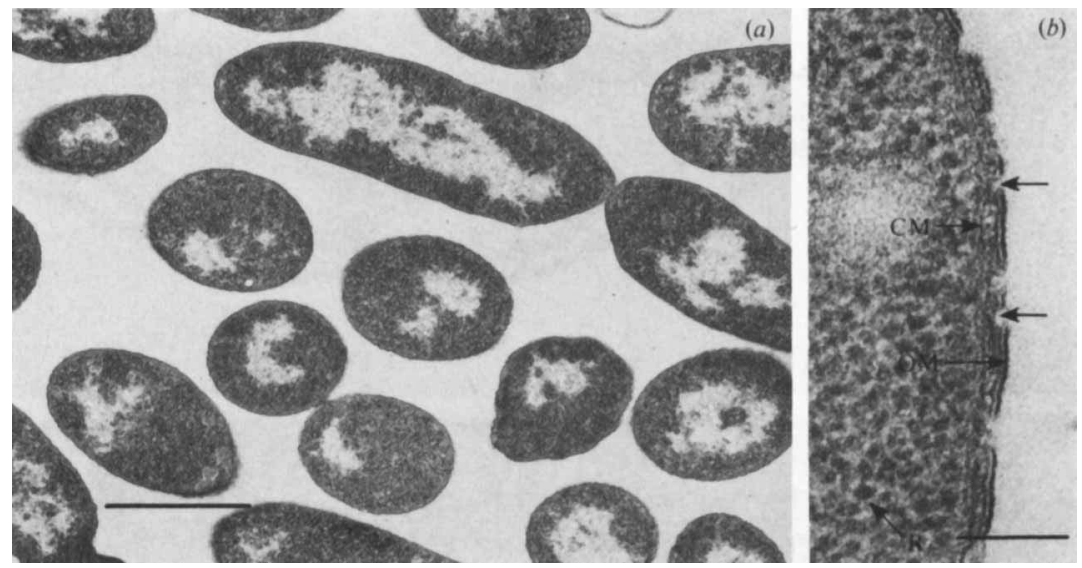

Fig. 9. (a) Ultrastructure of $P$. fluorescens cells $2 \mathrm{~h}$ after double-shock treatment with $\mathrm{Ca}^{2+}$ in sodium acetate buffer. No significant ultrastructural alterations are visible. Bar, $1 \mu \mathrm{m}$. (b) $P$. fluorescens cells $1 \mathrm{~h}$ after the double-shock; $\mathrm{Ca}^{2+}(10 \mathrm{mM})$ was added $30 \mathrm{~min}$ after the double-shock. Fractures of the outer membrane are visible (unlabelled arrows). CM, cytoplasmic membrane; OM, outer membrane; $R$, ribosome. Bar, $0 \cdot 1 \mu \mathrm{m}$.

\section{Effect of Triton $X-100$}

Treatment with 2 mM-Triton X-100 of cell suspensions made directly in distilled water induced a slight decrease in $A_{578}$ during the 50 to $60 \mathrm{~min}$ of the spectrophotometric study (Fig. 10). In all the other situations studied, including bacteria subjected to the double-osmotic shock with or without $\mathrm{Ca}^{2+}$ or $\mathrm{Mg}^{2+}$ (Fig. 11), or suspended in $0.5 \mathrm{M}$-sodium acetate buffer with or without $\mathrm{Ca}^{2+}$ or $\mathrm{Mg}^{2+}$ (Fig. 10), extensive cell lysis was induced by the detergent. 


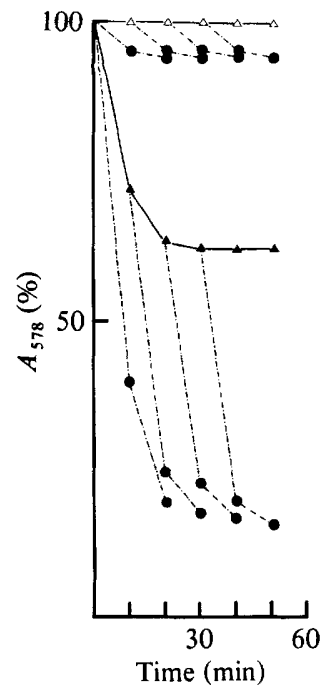

Fig. 10

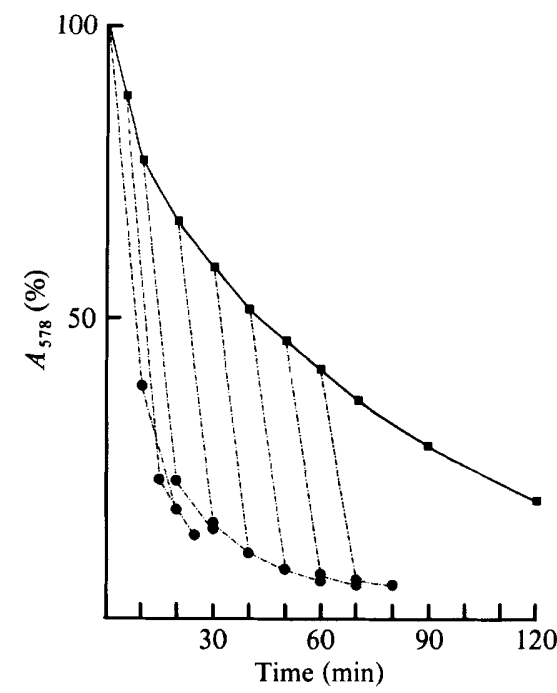

Fig. 11

Fig. 10. Effect of 2 mM-Triton X-100 on cell suspensions of $P$. fluorescens, made directly in distilled water $(\Delta)$ or in $0.5 \mathrm{M}$-sodium acetate, $\mathrm{pH} 6.5(\Delta)$; broken lines indicate the decrease in $\boldsymbol{A}_{578}$ after the addition of Triton $\mathrm{X}-100$ to cell suspensions at different times.

Fig. 11. Effect of $2 \mathrm{~mm}$-Triton X-100 added at different times during autolysis of $P$. fluorescens induced by double-shock treatment ( $\square$ ). Time 0 is at the beginning of autolysis, just after the double-shock; broken lines indicate the decrease in $A_{578}$ after the addition of Triton X-100 to autolysing cells.

\section{Effect of $N$-bromosuccinimide}

The addition of $N$-bromosuccinimide ( 1 or $2 \mathrm{mM}$ ) to cell suspensions just after the doubleosmotic shock strongly inhibited the autolytic process (when followed by turbidimetry). A $35 \%$ decrease in $A_{578}$ had occurred $1 \mathrm{~min}$ after the beginning of the incubation in the presence of 2 mM- $N$-bromosuccinimide. Two hours later, the $A_{578}$ was the same as that observed in the first minute. Examination of bacteria incubated under these conditions showed no plasmolysed cells and significant alterations (extensive splitting of, and occasional fractures in the outer membrane; cytoplasmic membrane and ribosomes not visible) after the first minute of incubation. The cells exhibited similar ultrastructural alterations $30 \mathrm{~min}$ and $2 \mathrm{~h}$ later, and there were no micromorphological signs of cell lysis. When $2 \mathrm{mM}-N$-bromosuccinimide was present in cell suspensions made directly in $0.05 \mathrm{M}$-phosphate buffer, the cells exhibited ultrastructural alterations similar to those described above.

\section{Effects of protein synthesis inhibitors}

The decrease in $A_{578}$ after the double-osmotic shock with cells from cultures exposed for $20 \mathrm{~min}$ to chloramphenicol $\left(100 \mu \mathrm{g} \mathrm{ml}^{-1}\right)$ or with cell suspensions with added chloramphenicol $\left(100 \mu \mathrm{g} \mathrm{ml}^{-1}\right)$ was reduced 7 and $17 \%$, respectively, compared to that of the autolytic process without chloramphenicol. One and two hours after the beginning of the autolytic process with chloramphenicol, the cells showed similar ultrastructural alterations to those observed in the autolytic process without the antibiotic. When tetracycline $\left(4.5 \mu \mathrm{g} \mathrm{ml}^{-1}\right)$ was used under the same conditions as chloramphenicol, the decrease in $A_{578}$ was 3 to $5 \%$ less than with chloramphenicol; the micromorphology of the cells $2 \mathrm{~h}$ after the osmotic shock was identical to that with chloramphenicol. The results were similar when the inhibitors of protein synthesis were used at a fivefold higher concentration (not shown). 


\section{DISCUSSION}

When bacteria lose the ability to regulate their autolysins, cell lysis may occur under specific conditions. The control of the autolysins of Gram-positive bacteria has been extensively studied and specific cell envelope components, such as lipoteichoic acids, were found to play an important role in the regulation of the endogenous autolytic system of Gram-positive bacteria (Cleveland et al., 1975, 1976a,b). Nevertheless, the mechanism(s) participating in the regulation and activation of the autolysins of Gram-negative bacteria remains largely unknown. In this paper we describe the ultrastructural alterations occurring in $P$. fluorescens during autolysis induced by osmotic shock and also the influence of several compounds on the autolytic process.

In our interpretation of the results it was assumed that treatment with distilled water followed by treatment with $0.5 \mathrm{M}$-sodium acetate, $\mathrm{pH} 6.5$, resulted in the removal of divalent cations from the bacterial envelopes (Leduc \& van Heijenoort, 1980). Since those cations stabilize membranous systems and peptidoglycan specific components in Gram-negative bacteria (Asbell \& Eagon, 1966; Boggis et al., 1979; Burton \& Carter, 1964; Eagon \& Carson, 1965; Schindler \& Osborn, 1979), the removal of cations would explain the increased permeability of the outer membrane in $P$. fluorescens subjected to double-osmotic shock. Such an increased permeability was demonstrated by the Triton X-100 experiments (see below) and is supported by ultrastructural observations of fractures in the outer membrane and changes in the profile from asymmetric to symmetric. This situation seems to be similar to that described for EDTA-treated E. coli (Bayer \& Leive, 1977; Leive, 1965; Leive et al., 1968). The removal of cations might also explain the alteration of the cytoplasmic membrane permeability (as deduced from cell deplasmolysis). We believe that, as a consequence of the damage to the cell envelope, there was an activation of the endogenous autolytic system of $P$. fluorescens, through an as yet unknown mechanism(s), with a progressive degradation of the peptidoglycan by the uncontrolled autolysins. Thus, the cell wall became unable to confer mechanical protection to the bacteria and, with the fragility of the cytoplasmic membrane (which was increased by the osmotic shock), there was a progressive cellular disintegration with leakage of macromoleculess - cell lysis.

Curiously, when the cells were suspended directly in $0.5 \mathrm{M}$-sodium acetate, $\mathrm{pH} 6.5$, fractures in the outer membrane and cell deplasmolysis became evident after the initial $30 \mathrm{~min}$, as in the autolytic process, but autolysis did not occur. The fact that the decrease in $A_{578}$ of cell suspensions made directly in sucrose or polyethylene glycol was less than that observed with $0.5 \mathrm{M}$-sodium acetate, together with the absence of autolysis when those compounds were used in the second treatment, suggests that sucrose and polyethylene glycol were less damaging to the cell envelopes than $0.5 \mathrm{M}$-sodium acetate. The formation of blebs of the outer membrane observed after treatment with distilled water has also been described in several situations of damage to the outer membrane (Katsui et al., 1982).

When $\mathrm{Ca}^{2+}$ or $\mathrm{Mg}^{2+}$ were present in the autolytic medium, there was a strong inhibition of the autolytic process. This suggests a lack of the expression of the activity of the bacterial autolytic endogenous system. The mechanism(s) preventing peptidoglycan degradation when $\mathrm{Ca}^{2+}$ or $\mathrm{Mg}^{2+}$ were present in the autolytic medium may be related to the action of divalent cations either on the cell envelope (peptidoglycan and membranous systems), as discussed above, or on the autolytic activity. Another possibility is that the presence of $\mathrm{Ca}^{2+}$ or $\mathrm{Mg}^{2+}$ in the autolytic medium resulted in the inactivation of the autolysins, for example by the formation of a complex with the cations which would abolish their degradative action on the peptidoglycan.

Our interpretation that the double-osmotic shock induces cell envelope damage is supported by the experiments with Triton X-100. Gram-negative bacteria are known to be resistant to this non-ionic detergent because the outer membrane is impermeable to it (Birdsell \& Cota-Robles, 1968). The occurrence of extensive lysis upon treatment with Triton X-100 is an indication that the cell wall had been rendered permeable to the detergent, which could, therefore, gain access to the cytoplasmic membrane. Extensive cell lysis was induced by the detergent, regardless of the presence of $\mathrm{Ca}^{2+}$ or $\mathrm{Mg}^{2+}$ in the autolytic medium or in the cell suspensions made directly in $0.5 \mathrm{M}$-sodium acetate, indicating that in all those situations the outer membrane had been damaged, allowing the detergent to gain access to the cytoplasmic membrane. 
A strong inhibition of the autolysis of $P$. fluorescens, as evaluated by spectrophotometry, was obtained with $N$-bromosuccinimide, an inhibitor of the autolysins of the Gram-positive bacteria (Cornett \& Shockman, 1978; Ramachandran \& Witkop, 1967). However, cell deplasmolysis occurred in the first minute after the addition of $N$-bromosuccinimide, indicating that it rapidly damaged the cytoplasmic membrane. $N$-Bromosuccinimide induces a chemical inactivation of enzyme molecules by reacting with tryptophan, tyrosine and histidine residues (Cornett \& Shockman, 1978; Ramachandran \& Witkop, 1967). The ultrastructural observations showed serious and generalized lesions when this inhibitor was present in the autolytic medium; such alterations may be due to the interaction of $N$-bromosuccinimide with bacterial proteins. Moreover, similar ultrastructural lesions were observed when $N$-bromosuccinimide was present in cell suspensions made directly in phosphate buffer. Consequently, the usefulness of this inhibitor for the study of the autolytic process appeared rather limited. The experiments carried out with the protein synthesis inhibitors chloramphenicol and tetracycline, known to be inhibitors of the autolysis of Gram-positive bacteria (Pooley \& Shockman, 1970; Sayare et al., 1972), showed little inhibition of the autolysis of $P$. fluorescens cells in comparison with the control. These results support the observation of Leduc et al. (1982) that chloramphenicol or rifampicin had little effect on autolysis induced by double-shock treatment of harvested cells.

In conclusion, our results show that a brief exposure of $P$. fluorescens to distilled water does not significantly affect the cell envelope; that treatment with $0.5 \mathrm{M}$-sodium acetate damages the outer membrane without inducing cell lysis; and that double-osmotic shock with distilled water followed by sodium acetate results in both outer membrane damage and cell lysis. Several stages could be defined by the ultrastructural analysis of the autolytic process. The membranous systems were altered by the double-shock treatment as shown by electron microscopy and Triton $\mathrm{X}-100$ experiments. Concomitant with this damage to the membranous systems, a generalized degradation of the peptidoglycan occurred as a result of the activation of the endogenous autolytic system. However, the mechanism(s) of the activation and regulation of the autolysins in $P$. fluorescens remains unknown. The autolysis rate we found after the double-shock treatment of $P$. fluorescens was higher than that reported by Leduc \& van Heijenoort (1980) for several strains of $E$. coli. This difference probably results from the known higher lability to lyse of $\boldsymbol{P}$. fluorescens which has a less resistant cell wall than that of the enteric Gram-negative bacteria (Costerton et al., 1979).

The authors are grateful to Mrs M. Andrea Costa and Miss M. Irene Barros for excellent technical assistance. The work was supported by INIC, Lisbon, Portugal.

\section{REFERENCES}

Asbell, M. A. \& EAGon, R. G. (1966). Role of multivalent cations in the organization, structure and assembly of the cell wall of Pseudomonas aeruginosa. Journal of Bacteriology 92, 380-387.

BAYER, M. E. \& LeIVE, L. (1977). Effect of ethylenediaminetetraacetate upon the surface of Escherichia coli. Journal of Bacteriology 130, 1364-1381.

Birdsell, D. C. \& Cota-Robles, E. H. (1968). Lysis of spheroplasts of Escherichia coli by a non-ionic detergent. Biochemical and Biophysical Research Communications 31, 438-446.

Boggis, W., KenWard, M. A. \& Brown, M. R. W. (1979). Effects of divalent metal cations in the growth medium upon sensitivity of batch-grown Pseudomonas aeruginosa to EDTA or polymyxin B. Journal of Applied Bacteriology 47, 477-488.

Burton, A. J. \& Carter, H. E. (1964). Purification and characterization of the lipid A component of the lipopolysaccharides from Escherichia coli. Biochemistry 3, 411-418.
Cleveland, R. F., Höltje, J. V., Wicken, A. J., Tomasz, A., Daneo-Moore, L. \& Shockman, G. D. (1975). Inhibition of bacterial wall lysins by lipoteichoic acids and related compounds. Biochemical and Biophysical Research Communications 67, 1128-1135.

Cleveland, R. F., Wicken, A. J., Daneo-Moore, L. \& Shockman, G. D. (1976a). Inhibition of wall autolysis in Streptococcus faecalis by lipoteichoic acid and lipids. Journal of Bacteriology 126, 192-197.

Cleveland, R. F., Daneo-Moore, L., Wicken, A. J. \& SHOCKMAN, G. D. (1976b). Effect of lipoteichoic acid and lipids on lysis of intact cells of Streptococcus faecalis. Journal of Bacteriology 127, 1582-1584.

CornetT, J. B. \& Shockman, G. D. (1978). Cellular lysis of Streptococcus faecalis induced with Triton X100. Journal of Bacteriology 135, 153-160.

Costerton, J. W., Brown, M. R. W. \& Sturgess, J. M. (1979). The cell envelope: its role in infection. In Pseudomonas aeruginosa, pp. 41-62. Edited by R. G. Doggett. London: Academic Press. 
Daneo-Moore, L. \& Shockman, G. D. (1977). The bacterial cell surface in growth and division. In The Synthesis, Assembly and Turnover of Cell Surface Components. Cell Surface Reviews, vol. 4, pp. 597715. Edited by G. Poste \& G. L. Nicolson. Amsterdam: North Holland Publishing Co.

EAGON, R. G. \& Carson, K. J. (1965). Lysis of cell walls and intact cells of Pseudomonas aeruginosa by ethylenediaminetetraacetic acid and by lysozyme. Canadian Journal of Microbiology 11, 193-201.

Epstein, W. \& SchulTZ, S. G. (1968). Ion transport and osmoregulation in bacteria. In Microbial Protoplasts, Spheroplasts and L-Forms, pp. 186-193. Edited by L. B. Guze. Baltimore: Williams \& Wilkins.

GHUYSEN, J. M. (1977). Biosynthesis, and assembly of bacterial cell walls. In The Synthesis, Assembly and Turnover of Cell Surface Components. Cell Surface Reviews, vol. 4, pp. 463-595. Edited by G. Poste \& G. L. Nicolson. Amsterdam: North Holland Publishing $\mathrm{Co}$.

Katsui, N., Tsuchido, T., Hiramatsu, R., Fujikawa, Fujikawa, S., Takano, M. \& Shibasaki, I. (1982). Heat-induced blebbing and vesiculation of the outer membrane of Escherichia coli. Journal of Bacteriology 151, 1523-1531.

Leduc, M. \& VAN Heijenoort, J. (1980). Autolysis of Escherichia coli. Journal of Bacteriology 142, 52-59.

Leduc, M., KasRa, R. \& van Heijenoort, J. (1982). Induction and control of the autolytic system of Escherichia coli. Journal of Bacteriology 152, 26-34.

LEIVE, L. (1965). Release of lipopolysaccharide by EDTA treatment of Escherichia coli. Biochemical and Biophysical Research Communications 21, 290-296.

Leive, L., Shovlin, V. K. \& Mergenhagen, S. E. (1968). Physical, chemical and immunological properties of lipopolysaccharide released from Escherichia coli by ethylenediaminetetraacetate. Journal of Biological Chemistry 243, 6384-6391.
LUFT, J. H. (1961). Improvements in epoxy resin embedding methods. Journal of Biophysical and Biochemical Cytology 9, 409-412.

MirelmaN, D. (1979). Biosynthesis and assembly of cell wall peptidoglycan. In Bacterial Outer Membranes. Biogenesis and Functions, pp. 115-166. Edited by $M$. Inouye. New York: John Wiley.

Pooley, H. M. \& Shockman, G. D. (1970). Relationship between the location of autolysis, cell wall synthesis and the development of resistance to cellular autolysis in Streptococcus faecalis after inhibition of protein synthesis. Journal of Bacteriology 103, 457466.

RAMAChandRan, L. K. \& WitKop, B. (1967), Nbromosuccinimide cleavage of peptides. Methods in Enzymology 11, 283-299.

RYter, A. \& Kellenberger, E. (1958). Étude au microscope électronique de plasmas contenant de l'acide désoxyribonucléique. I. Les nucléoïdes des bactéries en croissance active. Zeitschrift für Naturforschung 13b, 597-605.

Sayare, M., Daneo-Moore, L. \& Shockman, G. D. (1972). Influence of macromolecular biosynthesis on cellular autolysis in Streptococcus faecalis. Journal of Bacteriology 112, 337-344.

SCHINDLER, M. \& OSBORN, M. J. (1979). Interaction of divalent cations and polymyxin $B$ with lipopolysaccharide. Biochemistry 18, 4425-4430.

Shockman, G. D. (1965). Symposium on the fine structure and replication of bacteria and their parts. IV. Unbalanced cell wall synthesis: autolysis and cell wall thickening. Bacteriological Reviews 29, 345-358.

StolP, H. \& STARR, M. P. (1965). Bacteriolysis. Annual Review of Microbiology 19, 79-104.

Venable, J. H. \& COGgeshall, R. (1965). A simplified lead citrate stain for use in electron microscopy. Journal of Cell Biology 25, 407-408. 